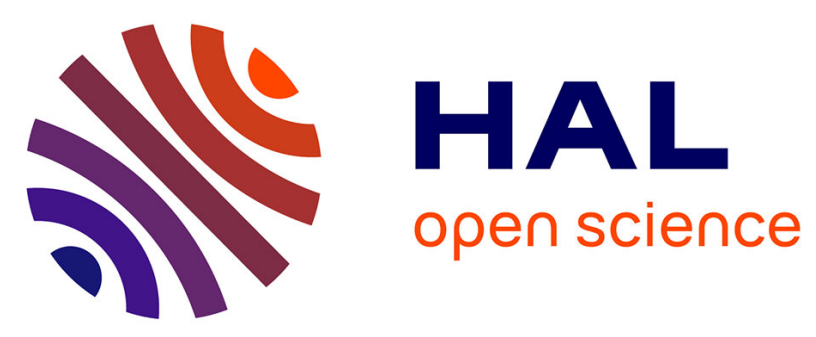

\title{
Proteomic analysis of secreted proteins from Arabidopsis thaliana seedlings: improved recovery following removal of phenolic compounds.
}

Stéphane Charmont, Elisabeth Jamet, Rafael Pont-Lezica, Hervé Canut

\section{To cite this version:}

Stéphane Charmont, Elisabeth Jamet, Rafael Pont-Lezica, Hervé Canut. Proteomic analysis of secreted proteins from Arabidopsis thaliana seedlings: improved recovery following removal of phenolic compounds.. Phytochemistry, 2005, 66 (4), pp.453-61. 10.1016/j.phytochem.2004.12.013 . hal00107439

\section{HAL Id: hal-00107439 \\ https://hal.science/hal-00107439}

Submitted on 18 Oct 2006

HAL is a multi-disciplinary open access archive for the deposit and dissemination of scientific research documents, whether they are published or not. The documents may come from teaching and research institutions in France or abroad, or from public or private research centers.
L'archive ouverte pluridisciplinaire HAL, est destinée au dépôt et à la diffusion de documents scientifiques de niveau recherche, publiés ou non, émanant des établissements d'enseignement et de recherche français ou étrangers, des laboratoires publics ou privés. 


\title{
Proteomic analysis of secreted proteins from Arabidopsis thaliana seedlings: improved recovery following removal of phenolic compounds
}

Stéphane Charmont, Elisabeth Jamet, Rafael Pont-Lezica, Hervé Canut*

UMR 5546 CNRS-Université Paul Sabatier, Pôle de Biotechnologie Végétale, BP17, 31326 Castanet-Tolosan, France

\section{Running Title: Proteomics of Arabidopsis secreted proteins}

*Corresponding author: Hervé Canut, UMR 5546 CNRS-UPS, BP 17 Auzeville, 31326

Castanet-Tolosan, France

E-mail: canut@scsv.ups-tlse.fr. Tel.: +33-5-62 1935 27. Fax: +33-5-62 193502

\begin{abstract}
Arabidopsis thaliana seedlings grown in liquid culture were used to recover proteins secreted from the whole plant. The aim was to identify apoplastic proteins that may be lost during classical extraction procedures such as preparation of cell walls. The inclusion of polyvinylpolypyrrolidone (PVPP) in the protocol of purification of secreted proteins allowed a more efficient identification of proteins after their separation by two-dimensional gel electrophoresis (2-DE) and mass spectrometry analyses. Improvement of identification was 4 fold. It is related to an increased number of detectable peaks on mass spectra increasing the percentage of sequence coverage, and the identification confidence. The role of PVPP was to trap phenolic compounds and to prevent their unspecific interactions with proteins. These experiments resulted in the identification of 44 secreted proteins, of which $70 \%$ were not identified in previous cell wall proteomic studies. This may be due to specific gene regulation in seedlings and /or to a better access to apoplastic proteins not bound to cell walls.
\end{abstract}

Keywords: Arabidopsis thaliana; Secreted proteins; Proteomics; Phenolic compounds; PV 


\section{Introduction}

The ultimate goal of proteomic analysis of a cell compartment should be an exhaustive enumeration of resident proteins excluding proteins from other cell compartments. Such a goal is closely linked to the reliability of isolation and purification techniques for the cell compartment of interest. Many proteins may be lost during the purification procedure, especially in the case of cell wall preparations (Watson et al., 2000; Chivasa et al., 2002; Pitarch et al., 2002). These secreted proteins can be recovered from the culture medium when cell suspension cultures are used, but not in the case of plant tissues or organs (Pardo et al., 2000; Borderies et al., 2003). Until now, this problem could only be overcome in the case of Arabidopsis thaliana rosettes by adaptation of the vacuum-infiltration technique, allowing the identification of a great number of apoplastic proteins in a non-destructive manner (Boudart et al., 2005). An alternative is to grow seedlings in liquid culture medium and to analyze the proteins present in this medium (Bardy et al., 1998).

Plant tissues are rich in phenolic compounds. They accumulate into the vacuole, the largest cell compartment of plant cells. Phenolics are also secreted either towards the cell wall where they polymerize into lignins (Harborne, 1980), or into the rhizosphere by roots (Phillips, 1992). Procedures for protein extraction should not only allow solubilization of all the proteins of interest, whatever their physico-chemical properties, but also prevent protein modification including oxidation. Moreover, when 2-DE is used, the purification procedure should eliminate compounds known to interfere with the electrophoresis, i.e. salts, lipids, polysaccharides, nucleic acids and phenolic compounds (Rabilloud, 1996; Fichmann and Westermeier, 1999). It has been known for decades that proteins might bind phenolic compounds in aqueous media through different mechanisms such as hydrogen, ionic bonding, and hydrophobic interactions (Pierpoint, 2004). The resulting product is more hydrophobic and susceptible to protein aggregation and precipitation. Some structural features of proteins such as proline-rich regions predispose them to such complexing (Baxter et al., 1997). Phenolic compounds can also form irreversible covalent linkages with proteins as a consequence of their oxidation to quinones (Pierpoint, 2004). Even though that problem was constantly underlined for enzymology studies, it was not yet specifically addressed for proteomic analysis.

In this work we have used Arabidopsis thaliana seedlings grown in liquid culture to recover the secreted proteins from the whole plant. Since culture media contain salts, organic compounds and secreted metabolites that may interfere with the separation and identification of proteins, we included water-insoluble polyvinyl-polypyrrolidone (PVPP) in the protein preparation protocol. Indeed, PVPP has been used for the removal of phenolic compounds including phenylpropanoid compounds and flavonoids from plant extracts, allowing the purification of proteins (Loomis, 1974; Pierpoint, 2004), RNAs (Salzman et al., 1999; Hu et al., 2002), and DNA (Young et al., 1993). We could show that the use of PVPP significantly improved the identification of proteins from culture medium by matrix-assisted laser desorption ionization-time of flight (MALDI-TOF) peptide mass fingerprinting, namely 4 fold. Forty-four secreted proteins could be identified among which 31 were not found in $A$. thaliana previous cell wall proteomic studies.

\section{Results and discussion}




\subsection{Isolation and separation of secreted proteins from culture medium of A. thaliana etiolated seedlings}

Two week-old seedlings grown in liquid medium in the dark were filtered and the culture medium collected. The culture medium was either directly processed, or mixed with water-insoluble PVPP, before being treated as described in Experimental. Upon concentration, the sample non-treated with PVPP became brown suggesting that proteins and phenols were oxidized. Since our previous work on cell wall proteins (CWP) indicated that most of them are basic (Borderies at al, 2003), we divided each sample to separate the proteins on regular (pH 4 to 7) and basic (pH 6 to 11) 2-D gels. The images of the resulting 2D gels did not show major differences between untreated (Fig. 1A, C) or PVPP-treated samples (Fig. 1B, D). In the same way, the amount of proteins in the two extracts were similar, i.e. $110 \mu \mathrm{g}$ proteins per flask of culture. Besides, if the oxidized phenolic compounds modify proteins by combining to their reactive groups, they do not seem to cause protein aggregation and precipitation. A. thaliana seedlings are not as rich in phenolics as green leaves or fruits. The likelihood of precipitation and aggregation is increased in the presence of large polyphenols that can interact with more than one protein molecule (Pierpoint, 2004).
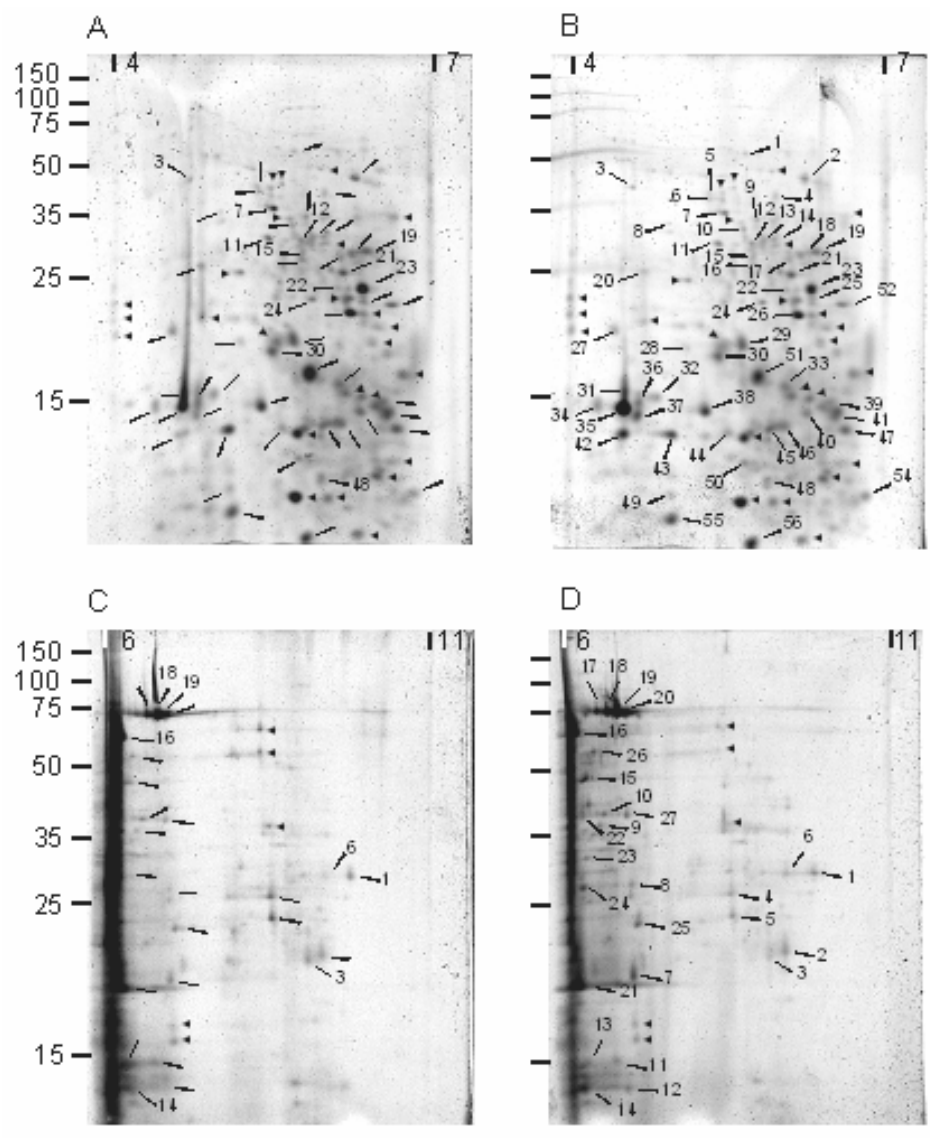

Figure 1. 2-D PAGE of proteins purified from liquid medium of 2 week-old etiolated seedlings. Protein samples were prepared in the absence $(\mathrm{A}, \mathrm{C})$ or in the presence of PVPP (B, D). They were separated by 2-DE using either a $\mathrm{pH} 4-7(\mathrm{~A}, \mathrm{~B})$ or a $\mathrm{pH}$ 6-11 (C, D) gradient in the first dimension. Gels were stained with SYPRO ${ }^{\circ}$ Ruby. The size of molecular mass markers in $\mathrm{kDa}$ is indicated towards the left of gels $\mathrm{A}$ and $\mathrm{C}$. Arrowheads indicate identified spots. Only the numbered spots were identified on the considered gel. indicate spots not identified over the 4 gels.

\subsection{Efficient recovery and improvement of protein identification by PVPP}

Phenolics, pigments and others coumpounds soluble in acetone are usually removed from the plant material of interest by a direct precipitation of proteins with TCA and acetone. However, the method leads to protein losses since not all the precipitated proteins can be resolubilized. When applied to our protein samples, only one fourth of the total proteins could 
be resolubilized. Many studies are presently devoted to improve that solubilization step in order to increase the number of proteins detectable by 2-DE (Jacobs et al., 2001; Giavalisco et al., 2003). In addition, when looking at a specific organelle proteome, sample preparation requires cell fractionation and purification in aqueous media, preventing direct protein precipitation from plant material. An alternative to the removal of phenolics from an aqueous medium is the addition of PVPP. Our results indicate that complexing phenolic compounds at a very early step of the procedure will be particularly useful for plant tissues rich in phenolic compounds and for plant cell compartments that accumulate them. In the case of the culture medium of $A$. thaliana etiolated seedlings, the adition of PVPP permits an efficient recovery of proteins for an improved identification by Maldi-TOF.

Overall, 112 protein spots were clearly resolved and reproducibly obtained after 2-DE. Trypsin-digested spots from both gels were submitted to MALDI-TOF mass spectrometry. Huge differences were found between the number of identified proteins through peptide mass fingerprinting in each case. For the PVPP-treated sample, $68-84 \%$ of the spots were identified compared to only $15-22 \%$ for the non-treated sample (Table 1 ). Comparison of MALDI-TOF spectra between non-treated (Fig. 2A) and treated samples (Fig. 2B) showed that the number of peptides above background is lower in the former case. In the treated sample most of the major peaks contribute to the identification of the protein. It was not possible to define clearly the physico-chemical properties of the peptides missing in non-treated samples, namely molecular mass or amino acid composition. Finally, the PVPP treatment enhanced the number of peptides matching a protein, rising significantly the percentage of sequence coverage and the level of confidence of the identification. One hypothesis is that PVPP binds phenolic compounds, which are then retained by the insoluble polymer probably avoiding further interactions with proteins. It is also possible that trypsin digestion was more effective in a cleaner protein solution than in an extract containing phenolic compounds.

Table 1. Influence of PVPP added during sample preparation on the efficiency of protein identification by peptide mass fingerprinting. Proteins were prepared as described in Experimental and submitted to 2-DE with the first dimension having a pH range of 4-7 or 6-11. After gel staining, spots were analyzed by MALDI-TOF-MS.

\begin{tabular}{|l|c|c|}
\hline & 2-DE pI 4 - 7 & 2-DE pI 6-11 \\
\hline $\begin{array}{l}\text { Total number of } \\
\text { analyzed spots }\end{array}$ & 81 & 32 \\
\hline $\begin{array}{l}\text { \% of identified spots } \\
\text { with PVPP }\end{array}$ & 68 & 84 \\
\hline $\begin{array}{l}\text { \% of identified spots } \\
\text { without PVPP }\end{array}$ & 15 & 22 \\
\hline
\end{tabular}

\subsection{Identification of proteins secreted in culture medium by etiolated seedlings}

Ninety-seven proteins were identified out of the total 112 spots analyzed from regular and basic 2-D gels. Since all the proteins came from the same culture medium, redundancy was found between gels and treatments. Altogether 48 proteins were identified, 44 being secreted and four intracellular contaminants. Thirty-one out of 44 CWP were not identified in 
previous proteomic studies using $A$. thaliana as the plant material. This study provides a new specific secreted protein pattern for seedlings. Among the 13 previously identified apoplastic proteins, 7 were common to rosettes (Boudart et al., 2005), and 7 to cell suspension cultures (Chivasa et al., 2002; Borderies et al., 2003). To detect which tissues were at the origin of the proteins found in the medium, we stained the seedlings with neutral red, a chemical used to stain the vacuoles. It was a way to test the permeability of the epidermis, and to evaluate the accessibility of apoplastic proteins. Fig. 3 showed that all the organs, cotyledons (Fig. 3A), hypocotyls (Fig. 3B), and roots (Fig. 3C), could be stained by neutral red. This showed indirectly the ability of the culture medium to wash out the proteins from the intercellular spaces of all seedling organs. Interestingly, about 50\% of proteins from seedling culture medium were acidic compared to only $20 \%$ of the proteins extracted from cell walls of cell suspension cultures or rosettes (Borderies et al., 2003; Boudart et al., 2005; Chivasa et al., 2002). It confirms that the identified proteins mainly originate from the apoplasm.
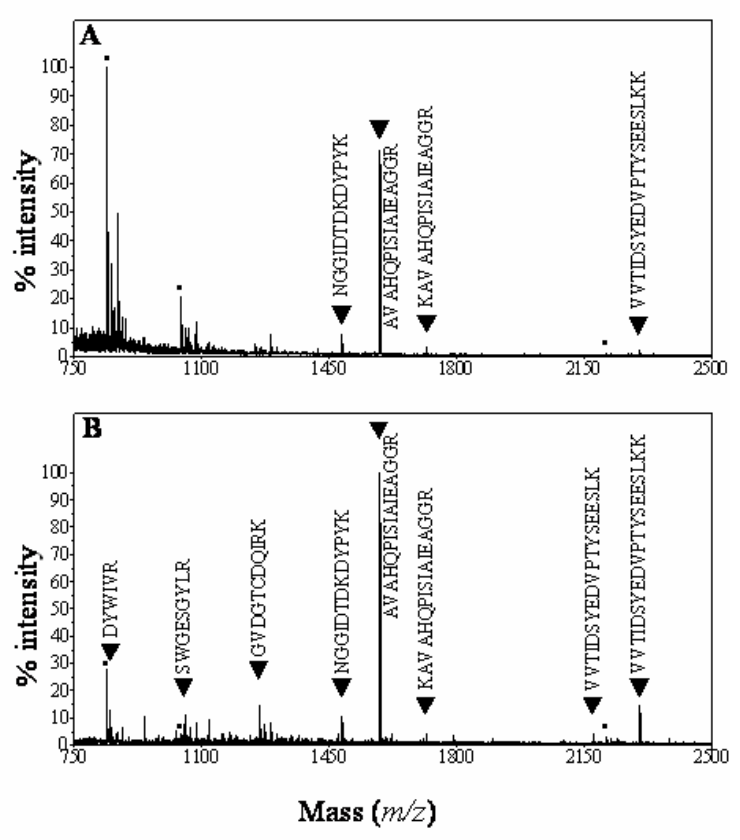

Figure 2. MALDI-TOF ion spectra generated from tryptic digests of spots A19 and B19. Spots 19 on gel A (no treatment) and gel B (treatment with PVPP) were excised (see Fig. 1), and were analyzed using MALDI-TOF MS after proteolytic digestion. Panel A is the spectrum obtained in the absence of PVPP: 4 peptides $(\boldsymbol{\nabla})$ allowed the identification of a cysteine proteinase RD 21A (Atlg47128). Panel $B$ is the spectrum in the presence of PVPP: 8 peptides $(\boldsymbol{\nabla})$ allowed the identification. Squares indicate peptides from autodigestion of trypsine.

Fig. 3. Staining of tissues from 2 week-old etiolated seedlings with neutral red. Seedlings were treated as described in Experimental to stain the vacuolar compartment with neutral red. Observations by bright field microscopy were done on cotyledon (A), hypocotyl (B) and root (C).

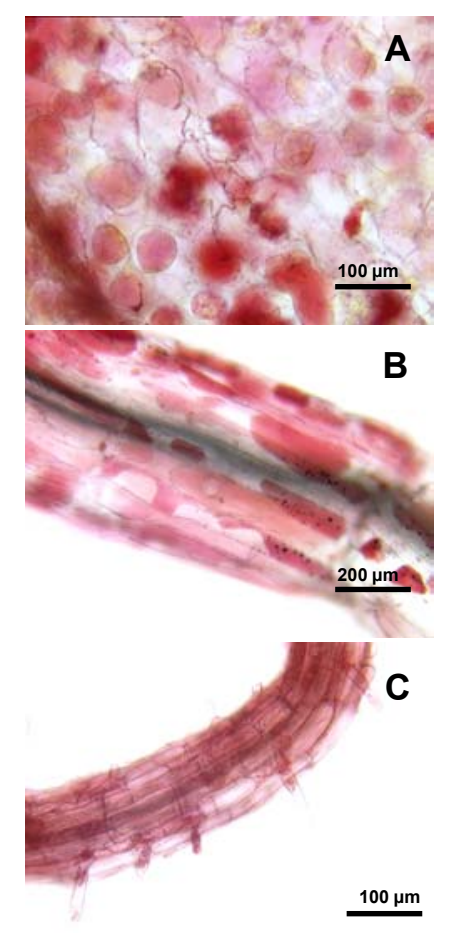


Table 2 presents all the identified secreted proteins classified into five categories according to their known functions or to predicted functional domains. Fig. 4 shows the arrangement of seedling secreted proteins into these functional classes. Almost half of them are proteins able to modify cell wall components: cell wall modifying proteins ( 10 glycosyl hydrolases, 2 polysaccharide lyases and 2 carbohydrate esterases), and oxido-reductases ( 8 peroxidases). Such classes of proteins represent most of the identified CWP in A. thaliana (Borderies et al., 2003; Boudart et al., 2005). Peroxidases were also abundant in cell suspension cultures, but only three peroxidases are common to both materials (At3g49120, $\underline{\text { At5g64120 }}$ and At2g18150). The following most abundant category is proteases with 10 proteins, 6 being members of the subtilisin family. This may explain why $70 \%$ of the identified proteins showed MM mobility in gels lower than expected. Proteolytic enzymes were also very abundant in rosette apoplasm fluids but only two of them were also found in seedling culture medium, At5g67360 and At1g01900, both members of the subtilisin family. Among miscellaneous proteins, three defense-related proteins were found (At3g04720,

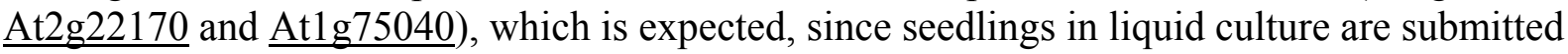
to mechanical and oxygen stresses. Surprisingly, none of these proteins was found in cell suspension cultures that may present the same type of stress. Contrary to what was found in previous cell wall proteomic studies, no protein containing interaction domains with other proteins or polysaccharides was identified. Such proteins are probably retained inside the cell wall matrix and require salt or chelating agents to be released from cell walls (Borderies et al., 2003; Boudart et al., 2005). All proteins of unknown function but one (At4g34180 also found in cell suspensions) were not yet found in the cell wall proteomes of rosettes or cell suspension cultures adding to the specificity of the protein profile of seedling culture medium

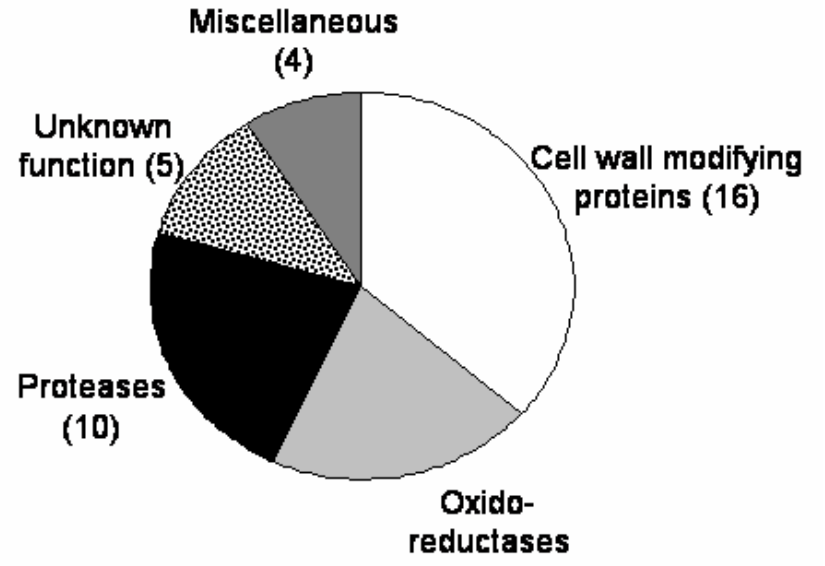

(9)
Figure 4. Distribution of proteins purified from liquid medium of 2 week-old etiolated seedlings in classes depending on their function or predicted functional domains

\section{Conclusions}

A proteomic analysis of secreted proteins from A. thaliana seedlings allowed the identification of a new set of apoplastic proteins. The inclusion of PVPP in the protocol of purification permitted an efficient recovery of proteins and a four-fold improvement of identification by MALDI-TOF. It could be related to an increased number of detectable peaks on mass spectra allowing an enhancement of sequence coverage and the confidence of identification. The role of PVPP was to trap phenolic compounds and to prevent their unspecific interactions with proteins. These experiments done on liquid medium of etiolated seedlings resulted in the identification of 44 secreted proteins, $70 \%$ of which were not identified in previous cell wall proteomic analyses. This may be due to specific regulation of 
gene expression in seedlings. Alternatively, it may show that many proteins are lost during cell wall preparations preceding protein elution. Analysis of culture medium would then give a better access to apoplastic proteins.

\section{Experimental}

\subsection{Plant material}

Seeds of $A$. thaliana ecotype Columbia $(100 \mathrm{mg})$ were germinated and grown in liquid medium in 11 flasks on a rotary shaker $(90 \mathrm{rpm})$ at $26^{\circ} \mathrm{C}$ in the dark, as previously described (Bardy et al., 1998). Each flask contained $130 \mathrm{ml}$ of Murashige and Skoog (1962) liquid medium (Sigma Chemical, St Louis, MO, USA) supplemented with $10 \mathrm{~g} / 1$ sucrose and adjusted to $\mathrm{pH} 5.8$ with $\mathrm{KOH}$. After 14 days, etiolated seedlings were harvested and the culture medium was filtered through nylon net $(60 \mu \mathrm{m})$ to remove cell debris.

\subsection{Sample preparation}

Nine hundreds $\mathrm{ml}$ of culture medium were collected from 10 flasks and divided into two equal parts. One of them was mixed with $1 \mathrm{~g}$ PVPP (Sigma Chemical, St Louis, MO, USA)/100 ml of medium. Before use, the commercial PVPP was treated with acid to increase polymerization and to remove metal ions and contaminants. One $\mathrm{g}$ PVPP/10 $\mathrm{ml} \mathrm{HCl} \mathrm{10 \%} \mathrm{was}$ boiled for $10 \mathrm{~min}$, filtered through a G4 filter, and rinsed until neutral $\mathrm{pH}$ was reached. The residue was dehydrated with acetone and ground in a mortar to obtain a fine powder (Loomis, 1974). The culture medium/PVPP mixture was shaken at $4{ }^{\circ} \mathrm{C}$ for at least $30 \mathrm{~min}$, filtered and centrifuged to pellet the insoluble residue. Both culture media (treated and non-treated with PVPP) were dialyzed against 101 distilled water during $10-12 \mathrm{~h}$ at $4{ }^{\circ} \mathrm{C}$ using a cellulose membrane (MWCO: 12000 Da, Spectra/Por ${ }^{\circledR}$, Spectrum Medical Industries Inc, Houston, TE, USA) with 3 changes. The volume of the samples was reduced by repeated centrifugations $\left(3500 \mathrm{x} g\right.$ for $15 \mathrm{~min}$ at $4{ }^{\circ} \mathrm{C}$ ) through a Centriprep ${ }^{\circledR}$ system (MWCO: 10000 Da, Millipore Corporation, Bedford, MA, USA) to about $1 \mathrm{ml}$. Quantification of proteins was achieved using the modified Bradford protein assay (Coomassie ${ }^{\circledR}$ Protein assay Reagent Kit, Pierce, Rockford, IL, USA) (Ramagli and Rodriguez, 1985).

\subsection{Protein separation by 2-DE}

For the first dimension, immobilized $\mathrm{pH}$ gradient (IPG) gel strips (13 cm, pH 4-7 or 6-11, Amersham Pharmacia Biotech, Uppsala, Sweden) were rehydrated overnight in a reswelling tray (Amersham Pharmacia Biotech) at room temperature. For each IPG gel strip, $250 \mu \mathrm{g}$ proteins extracted from culture medium were diluted with $250 \mu 1$ rehydration buffer composed of $7 \mathrm{M}$ urea, $2 \mathrm{M}$ thiourea, $4 \%$ (w/v) CHAPS, $65 \mathrm{mM}$ DTE, 0.5\% (v/v) IPG buffer, pH 4-7 or 6-11, bromophenol blue trace, and covered with mineral oil (Rabilloud, 1998). Prior to IEF, the rehydrated IPG gel strips were rinsed with distilled water for $1 \mathrm{~s}$ and then blotted between 2 sheets of moist filter paper to remove excess reswelling solution. This was done to avoid urea crystallization on the gel surface, which is held responsible for prolonged IEF and "empty" vertical lanes in the stained 2-DE pattern. IEF was conducted using Multiphor II systems at $20{ }^{\circ} \mathrm{C}$ (Amersham Pharmacia Biotech) with a 4-phase program: from 0 to $300 \mathrm{~V}$ for $1 \mathrm{~min}, 300 \mathrm{~V}$ for $3 \mathrm{~h}$, linear gradient ranging from $300 \mathrm{~V}$ to $3500 \mathrm{~V}$ in $1 \mathrm{~h}$, $3500 \mathrm{~V}$ for $20 \mathrm{~h}$. Current and power settings were limited to $40 \mathrm{~mA}$ and $5 \mathrm{~W}$ per IPG gel strip, respectively. After focusing, the IPG gel strips were placed in a screw-cap tube. The equilibration buffer was $6 \mathrm{M}$ urea, 30\% glycerol, 2\% SDS, $50 \mathrm{mM}$ Tris- $\mathrm{HCl} \mathrm{pH} 8.8$ and a 
trace of bromophenol blue. Ten $\mathrm{ml}$ of $2 \%$ DTE-containing equilibration buffer was added to each tube. The strips were then equilibrated for $15 \mathrm{~min}$ on an orbital shaker. The first equilibration solution was decanted and replaced by $10 \mathrm{ml}$ of $2.5 \%$ iodoacetamide-containing equilibration buffer. It was equilibrated for another $15 \mathrm{~min}$ on an orbital shaker. Prior to second dimension, the IPG gel strips were rinsed with electrode buffer ( $25 \mathrm{mM}$ Tris, $192 \mathrm{mM}$ glycine, $0.1 \% \mathrm{w} / \mathrm{v}$ SDS) for $1 \mathrm{~s}$. The second dimension was performed using a vertical slab gel (Protean II, $20 \mathrm{~cm}$, Biorad Laboratories, Hercules, CA, USA) according to Laemmli (1970). After equilibration, the IPG gel strips were placed on top of the resolving polyacrylamide gel (gel thickness was $1 \mathrm{~mm}$, acrylamide concentration 12.5\%). The second dimension gels were then overlaid with molten $0.8 \%$ agarose solution in electrode buffer (adding a trace of bromophenol blue). Electrophoresis was performed at $5 \mathrm{~mA}$ overnight at 20 ${ }^{\circ} \mathrm{C}$. After electrophoresis, gels were fixed for 30 min using $20 \%$ methanol, $7.5 \%$ acetic acid. They were subsequently stained overnight using the SYPRO Ruby Protein Gel Stain (Molecular Probes, Leiden, NL). Prior to scanning, gels were briefly washed in $20 \%$ methanol, 7.5\% acetic acid, and 5\% glycerol. They were stored in this solution at $4{ }^{\circ} \mathrm{C}$ (Rabilloud and Charmont, 1999).

\subsection{Protein identification by mass spectrometry and bioinformatics}

Protein spots were excised from stained gels and characterized after in-gel trypsin digestion by MALDI-TOF mass spectrometry (MS), using a Voyager-DE ${ }^{\mathrm{TM}}$ STR mass spectrometer (PerSeptive Biosystems, Framingham, MA, USA) (Borderies et al., 2003). The retained parameters were mass tolerance $\pm 20 \mathrm{ppm}$, one missed cleavage, and at least four trypsin peptide matches, except for some proteins of experimental molecular mass lower than $20 \mathrm{kDa}$ where three trypsin peptide matches were considered satisfactory. Identification of proteins and bioinformatic analyses of protein sequences were performed as previously described (Borderies et al., 2003; Boudart et al., 2005).

\subsection{Microscopic observations}

A. thaliana seedlings were incubated for $30 \mathrm{~min}$ in $50 \mathrm{mM}$ Tris $\mathrm{pH} 8.0(\mathrm{HCl})$. After a brief rinse in distilled water, seedlings were immersed in $0.05 \%$ neutral red solution for 5 to 10 min. The excess of stain was removed from tissues by a second rinse in distilled water, and the seedlings were then plasmolyzed in a solution of $0.5 \mathrm{M}$ mannitol or $0.3 \mathrm{M} \mathrm{CaCl}_{2}$. Seedlings were observed with Leitz DB-IRBE inverted microscope in bright field. Images were acquired with a CCD camera (Colour Coolview, Photonic Science Ltd, Robertsbridge, East Sussex, UK), and Image-ProPlus image analysis software (Media Cybernetics Inc, Silver Spring, MD, USA).

\section{Acknowledgements}

This work was supported by GABI-Genoplante (Contract No AF-2001091), Génoplante (Contract No NO-2001027), the Centre National de la Recherche Scientifique, and the Université Paul Sabatier de Toulouse, France. Mass spectrometry analyses were performed on the Plate-Forme de Spectrométrie de Masse in Auzeville, France. 


\section{References}

Bardy, N., Carrasco, A., Galaud, J. P., Pont-Lezica, R. Canut, H., 1998. Free-flow electrophoresis for fractionation of Arabidopsis thaliana membranes. Electrophoresis 19, 1145-1153.

Baxter, N. J., Lilley, T. H., Haslam, E. Williamson, M. P., 1997. Multiple interactions between polyphenols and a salivary proline-rich protein repeat result in complexation and precipitation. Biochemistry 36, 5566-5577.

Borderies, G., Jamet, E., Lafitte, C., Rossignol, M., Jauneau, A., Boudart, G., Monsarrat, B., Esquerré-Tugayé, M. T., Boudet, A. Pont-Lezica, R., 2003. Proteomics of loosely bound cell wall proteins of Arabidopsis thaliana cell suspension cultures: A critical analysis. Electrophoresis 24, 3421-3432.

Boudart, G., Jamet, E., Rossignol, M., Lafitte, C., Borderies, G., Jauneau, A., EsquerréTugayé, M. T. Pont-Lezica, R., 2005. Cell wall proteins in apoplastic fluids of Arabidopsis thaliana rosettes: identification by mass spectrometry and bioinformatics. Proteomics, in press.

Chivasa, S., Ndimba, B. K., Simon, W. J., Robertson, D., Yu, X.-L., Knox, J. P., Bolwell, P. Slabas, A. R., 2002. Proteomic analysis of the Arabidopsis thaliana cell wall. Electrophoresis 23, 1754-1765.

Fichmann, J. Westermeier, R., 1999. 2-D protein gel electrophoresis. An overview. Methods Mol. Biol. 112, 1-7.

Giavalisco, P., Nordhoff, E., Lehrach, H., Gobom, J. Klose, J., 2003. Extraction of proteins from plant tissues for two-dimensional electrophoresis analysis. Electrophoresis 24, 20716.

Harborne, J. B. 1980. Plant phenolics. In: Bell, E. Charlwood, B. (Eds.) Encyclopedia of Plant Physiology, Vol. 8. Springer-Verlag, Berlin, pp. 329-402.

Hu, C. G., Honda, C., Kita, M., Zhang, Z., Tsuda, T. Moriguchi, T., 2002. A simple protocol for RNA isolation from fruit trees containing high levels of polysaccharides and polyphenol compounds. Plant Mol. Biol. Rep. 20, 69a-69g.

Jacobs, D. I., van Rijssen, M. S., van der Heijden, R. Verpoorte, R., 2001. Sequential solubilization of proteins precipitated with trichloroacetic acid in acetone from cultured Catharanthus roseus cells yields 52\% more spots after two-dimensional electrophoresis. Proteomics 1, 1345-1350.

Laemmli, U. K., 1970. Cleavage of structural proteins during the assembly of the head of bacteriophage T4. Nature 227, 680-685.

Loomis, W. D., 1974. Overcoming problems of phenolics and quinones in the isolation of plant enzymes and organelles. Methods in Enzymology 31, 528-545.

Murashige, T. Skoog, F., 1962. A revised medium for rapid growth and bioassays with tobacco tissue culture. Physiol Plant 15, 473-497.

Pardo, M., Ward, M., Bains, S., Molina, M., Blackstock, W., Gil, C. Nombela, C., 2000. A proteomic approach for the study of Saccharomyces cerevisiae cell wall biogenesis. Electrophoresis 21, 3396-3410.

Phillips, D. A., 1992. Flavonoids: plant signals to soil microbes. Recent Adv. Phytochem. 26, 201-230.

Pierpoint, W. S., 2004. The extraction of enzymes from plant tissues rich in phenolic compounds. Methods Mol. Bio. 244, 65-74. 
Pitarch, A., Sanchez, M., Nombela, C. Gil, C., 2002. Sequential fractionation and twodimensional gel analysis unravels the complexity of the dimorphic fungus Candida albicans cell wall proteome. Mol. Cell Proteomics 1, 967-982.

Rabilloud, T., 1996. Solubilization of proteins for electrophoretic analyses. Electrophoresis 17, 813-829.

Rabilloud, T., 1998. Use of thiourea to increase the solubility of membrane proteins in twodimensional electrophoresis. Electrophoresis 19, 758-760.

Rabilloud, T. Charmont, S. 1999. Detection of proteins on two-dimensional electrophoresis gels.In: Rabilloud, T. (Eds.) Proteome Research: Two-dimensional Electrophoresis and Identification Methods. Springer, Berlin, Heidelberg, pp.107-126.

Ramagli, L. S. Rodriguez, L. V., 1985. Quantitation of microgram amounts of protein in twodimensional polyacrylamide electrophoresis sample buffer. Electrophoresis 6, 559-563.

Salzman, R. A., Fujita, T., Zhu-Salzman, K., Hasegawa, P. M. Bressan, R. A., 1999. An improved RNA isolation method for plant tissues containing high levels of phenolic compounds or carbohydrates. Plant Mol. Biol. Rep. 17, 11-17.

Watson, B. S., Lei, Z., Dixon, R. A. Sumner, L. W., 2004. Proteomics of Medicago sativa walls. Phytocemistry 65, 1709-1720.

Young, C. C., Burghoff, R. L., Keim, L. G., Minak-Bernero, V., Lute, J. R. Hinton, S. M., 1993. Polyvinylpyrrolidone-agarose gel electrophoresis purification of polymerase chain reaction-amplifiable DNA from soils. Appl. Environ. Microbiol. 59, 1972-1974. 
Table 2. Proteins identified in the culture medium of 2 week- old etiolated seedlings grown in liquid medium

Proteins were separated and identified by MALDI-TOF-MS. Functions or putative functions were defined after a bioinformatic analysis, following the TIGR database annotation and the CAZy nomenclature for carbohydrate-linked enzymes. Secreted proteins were distributed in functional classes.

\begin{tabular}{|c|c|c|c|c|c|c|c|c|}
\hline Protein identification & Spot number ${ }^{a}$ & $\begin{array}{l}\text { Gene acc. } \\
\text { number }\end{array}$ & $\begin{array}{c}\text { Signal } \\
\text { peptide }\end{array}$ & \multicolumn{2}{|c|}{ Theoretical $^{\mathrm{c}}$} & \multicolumn{2}{|c|}{ Experimental $^{\mathrm{d}}$} & $\begin{array}{c}\% \\
\text { coverage }^{\mathrm{e}}\end{array}$ \\
\hline $\begin{array}{l}\text { Glycoside hydrolase family } 3 \text { (beta- } \\
\text { xylosidase) (XYL4) }\end{array}$ & $\begin{array}{l}\text { A9-B9, A24-B24, } \\
\text { A26-B26, A34- } \\
\text { B34, C5-D5, } \\
\text { C16-D16 }\end{array}$ & At5g64570 & $\begin{array}{c}1-38 \\
(0.820)\end{array}$ & 80.0 & 7.0 & $\begin{array}{l}64.3- \\
14.6\end{array}$ & $8.6-4.3$ & $\begin{array}{c}15 \\
(19)\end{array}$ \\
\hline $\begin{array}{l}\text { Glycoside hydrolase family } 9 \\
\text { (cellulase) }\end{array}$ & C5-D5 & At4g09740 & $(0.685)$ & 50.2 & 6.1 & 24.0 & 8.6 & $\begin{array}{c}11 \\
(23)\end{array}$ \\
\hline $\begin{array}{l}\text { Glycoside hydrolase family } 16 \\
\text { (xyloglucan:xyloglucosyl transferase) } \\
\text { (XTR6) (At-XTH23) }\end{array}$ & A15-B15, A16-B16 & At4g25810 & $\begin{array}{c}1-24 \\
(0.820)\end{array}$ & 29.6 & 4.8 & $\begin{array}{l}27.5- \\
26.5\end{array}$ & 5.7 & 13 \\
\hline $\begin{array}{l}\text { Glycoside hydrolase family } 17 \text { (glucan } \\
\text { endo-1,3-D-glucosidase ) }\end{array}$ & C9-D9, C13-D13 & At3g57270 & $\begin{array}{c}1-20 \\
(0.571)\end{array}$ & 35.4 & 9.3 & $\begin{array}{c}36.6- \\
14.7\end{array}$ & $6.7-6.4$ & 12 \\
\hline $\begin{array}{l}\text { Glycoside hydrolase family } 28 \\
\text { (polygalacturonase) }\end{array}$ & A33-B33 & At2g33160 & $\begin{array}{c}1-20 \\
(0.820)\end{array}$ & 75.0 & 9.7 & 15.9 & 6.1 & $\begin{array}{c}12 \\
(56)\end{array}$ \\
\hline $\begin{array}{l}\text { Glycoside hydrolase family } 29 \text { (alpha- } \\
\text { L-fucosidase) }\end{array}$ & A5-B5 & At2g28100 & $\begin{array}{c}1-18 \\
(0.590)\end{array}$ & 55.1 & 5.1 & 41.1 & 5.3 & $\begin{array}{c}9 \\
(12)\end{array}$ \\
\hline $\begin{array}{l}\text { Glycoside hydrolase family } 35 \text { (beta- } \\
\text { galactosidase) }\end{array}$ & $\mathrm{C} 25-\mathrm{D} 25$ & At1g77410 & $\begin{array}{c}1-19 \\
(0.820)\end{array}$ & 89.6 & 9.9 & 23.3 & 7.2 & $\begin{array}{c}9 \\
(35)\end{array}$ \\
\hline $\begin{array}{l}\text { Glycoside hydrolase family } 51 \text { (alpha- } \\
\text { arabinofuranosidase) }\end{array}$ & A4-B4 & At3g10740 & $\begin{array}{c}1-20 \\
(0.752)\end{array}$ & 72.6 & 5.3 & 40.2 & 5.9 & $\begin{array}{c}4 \\
(7)\end{array}$ \\
\hline
\end{tabular}




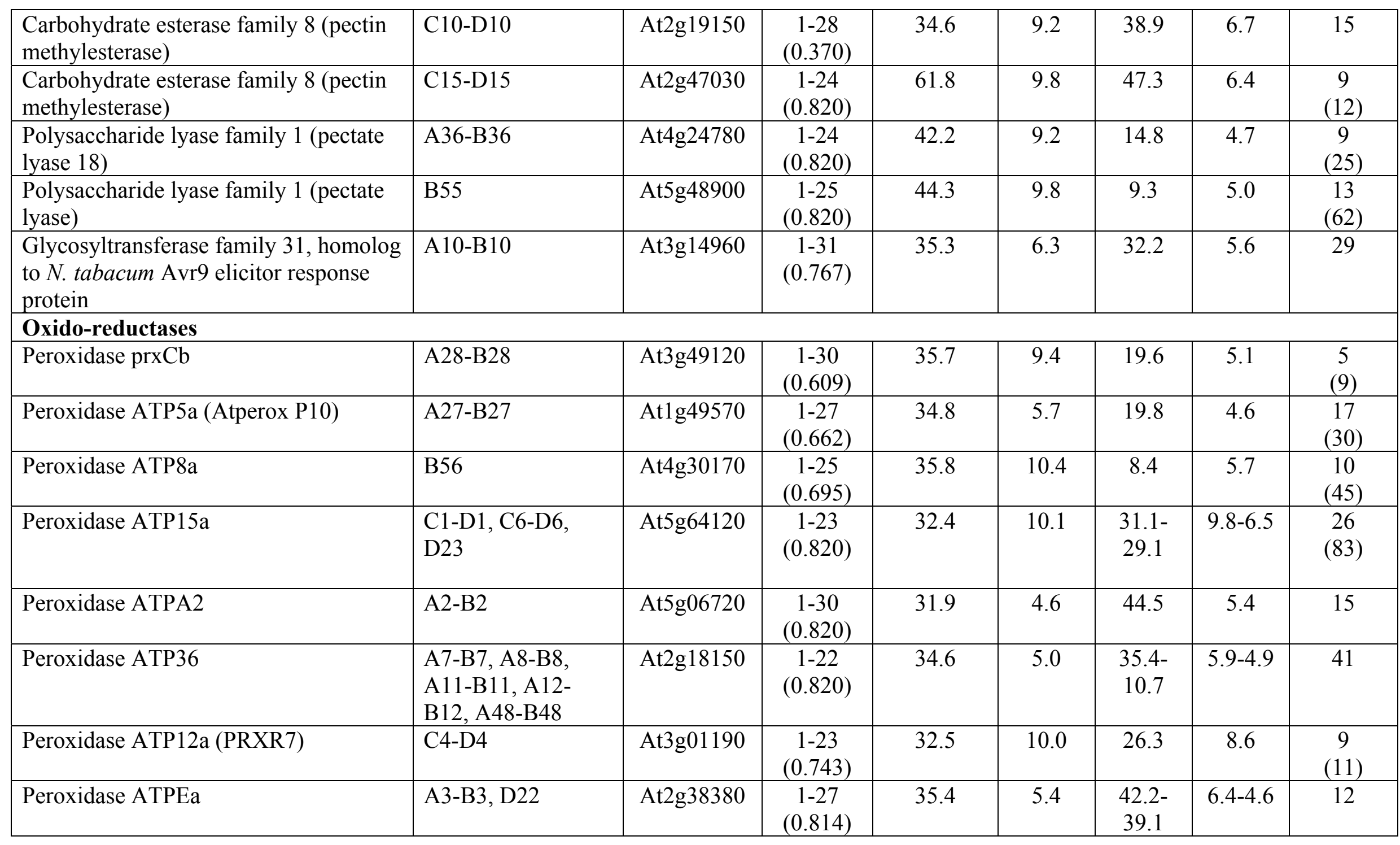




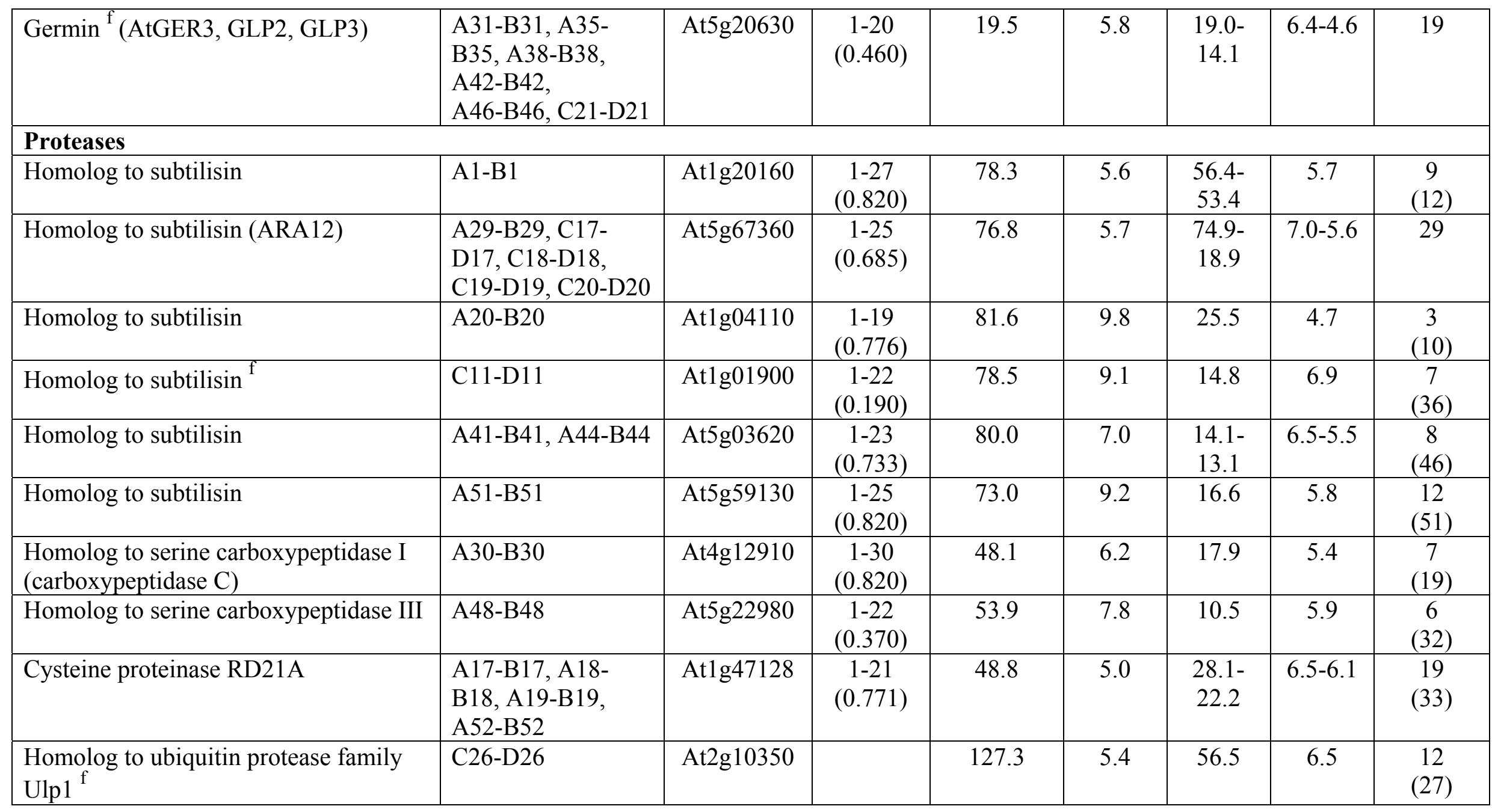




\begin{tabular}{|c|c|c|c|c|c|c|c|c|}
\hline \multicolumn{9}{|l|}{ Miscellaneous } \\
\hline Homolog to blue copper binding protein & C2-D2, C3-D3 & At4g12880 & $\begin{array}{c}1-18 \\
(0.820)\end{array}$ & 14.3 & 9.6 & $\begin{array}{c}21.4- \\
21.0\end{array}$ & $9.6-9.2$ & 35 \\
\hline Weakly homolog to acid phosphatase & A54-B54 & At1g09870 & $\begin{array}{c}1-19 \\
(0.499)\end{array}$ & 52.7 & 9.1 & 10.2 & 6.6 & $\begin{array}{c}14 \\
(74)\end{array}$ \\
\hline $\begin{array}{l}\text { Homolog to B. napus dehydratation } \\
\text { stress-induced protein }\end{array}$ & A39-B39 & At2g22170 & $\begin{array}{c}1-21 \\
(0.820)\end{array}$ & 17.8 & 4.7 & 14.6 & 6.4 & 24 \\
\hline Thaumatin-like (PR5) & $\begin{array}{l}\text { A23-B23, A25- } \\
\text { B25, A50-B50 }\end{array}$ & At1g75040 & $\begin{array}{c}1-20 \\
(0.820)\end{array}$ & 23.1 & 4.4 & $\begin{array}{c}23.5- \\
11.7\end{array}$ & $6.3-5.7$ & 18 \\
\hline Expressed protein & A47-B47 & At5g23830 & $\begin{array}{c}1-25 \\
(0.820)\end{array}$ & 15.3 & 4.1 & 13.2 & 6.6 & 26 \\
\hline Expressed protein & A49-B49, C24-D24 & At4g34180 & $\begin{array}{c}1-24 \\
(0.820)\end{array}$ & 25.8 & 5.6 & $\begin{array}{c}28.0- \\
10.3\end{array}$ & $6.5-5.0$ & 31 \\
\hline Expressed protein ${ }^{f}$ & A40-B40 & At3g07470 & $\begin{array}{c}1-24 \\
(0.460)\end{array}$ & 16.2 & 4.7 & 14.2 & 6.3 & 23 \\
\hline \multicolumn{9}{|l|}{ Intracellular proteins } \\
\hline $\operatorname{Actin}^{\mathrm{g}}$ (ACT3 and/or ACT1) & A6-B6 & $\begin{array}{l}\text { At3g53750 } \\
\text { At2g37620 }\end{array}$ & & 41.8 & 5.1 & 39.2 & 5.3 & 12 \\
\hline Homolog to major latex protein & A30-B30 & At2g01520 & & 17.6 & 5.2 & 17.9 & 5.4 & 33 \\
\hline Homolog to jacalin & $\begin{array}{l}\text { A13-B13, A14- } \\
\text { B14, A21-B21, } \\
\text { A22-B22, } \\
\text { A45-B45 }\end{array}$ & At3g16400 & & 51.7 & 5.1 & $\begin{array}{c}30.4- \\
13.3\end{array}$ & $6.1-5.9$ & $\begin{array}{c}26 \\
(45)\end{array}$ \\
\hline Homolog to jacalin & $\begin{array}{l}\text { A37-B37, A43- } \\
\text { B43, C14-D14 }\end{array}$ & At3g16420 & & 32.2 & 5.6 & $\begin{array}{c}14.8- \\
13.1\end{array}$ & $6.4-4.7$ & $\begin{array}{c}16 \\
(34)\end{array}$ \\
\hline
\end{tabular}


${ }^{\mathrm{a}}$ spot numbers refer to Figure 1

${ }^{b}$ values between brackets are PSORT scores for prediction of localization of proteins outside the cells or in the plasma membrane

${ }^{\mathrm{c}}$ theoretical molecular masses (MM) and $\mathrm{pI}$ have been calculated for mature proteins

$\mathrm{d}$ experimental MM are the means of values obtained from the pairs of 2D-gels (A and B, C and D). Extreme observed values are reported.

${ }^{\mathrm{e}} \%$ coverages are given by the MS-FIT software (http://prospector.ucsf.edu/ucsfhtml4.0/msfit.htm). They are calculated with the total number of amino acids of proteins. In order to take into account the reduction in size of proteins due to proteolysis, a new calculation was done and is indicated between brackets.

${ }^{\mathrm{f}}$ protein predicted to have transmembrane domains

$\mathrm{g}$ there are two conserved actin genes. The peptides obtained matched the two deduced proteins and it was not possible to discriminate between them. 